\title{
Moment of Citizenship: Association and Aspiration of Minahasan, North Sulawesi
}

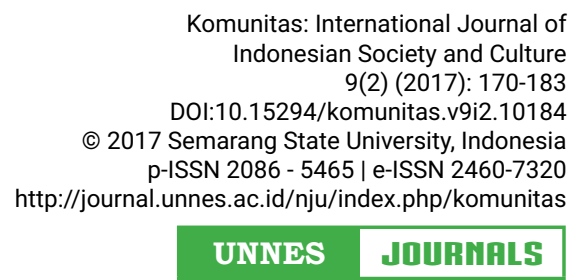

UNNES

\author{
Basri Amin ${ }^{1}$ \\ ${ }^{1}$ Research Institute for School \& Society, Faculty of Education, Universitas Negeri Gorontalo, Indonesia
}

Received: July 2017; Accepted: August 2017; Published: September 2017

\begin{abstract}
This article is about Minahasa, an ethnic group in North Sulawesi, Indonesia. This article analyzes the dynamics of Minahasan collective actions in early 2000 in responding to the sectarian debates throughout the Indonesian archipelago where the issues of religion and ethnicity are flourishing. I draw on case studies from Kongres Minahasa Raya (the Great Congress of Minahasan) as entry point to explore the ways Minahasans have been peacefully demanding serious attention to and clarification on constitutionally-based provisions of citizenship in Indonesia. It is my hope that this article will show how such "collective strategies" are created and maintained by Minahasans. This is an example of an ongoing feature of how citizens' arenas and rights are contested in contemporary Indonesia.
\end{abstract}

\section{Keywords}

Minahasa; citizenship; Christianity; ethnicity

\section{INTRODUCTION}

Minahasa is an ethnic group. Minahasans are Christians and are recognized as a distinctive religious group in Indonesia. In fact, Minahasans are an example of an ethnic diaspora whereby a significant number of them are living outside of Minahasan territory. However, Minahasan history and experience of resistance from communal or primordial conflicts reinforce their internal concept of identity and collective interests in plural society.

Although Minahasa is a "minority" in Indonesia, this paper argues that Minahasa is unique in terms of the development and articulation of collective identity. Minaha- sans have created and maintained certain images, agendas and actions in history that are easily recognized by other communities including the state. Arguably, Christianity has successfully brought Minahasan society and its life practices and imagination to the outside world. On the one hand, Minahasans have projected themselves as representatives of the modern ethnic community given their exposure to European influences (culture and religion) in Minahasan region since the eighteenth century; but during

\footnotetext{
Corresponding author

Jl. Sudirman No. 06 Kota Gorontalo, 96128, Indonesia Email

basri@ung.ac.id
} 
the past decades, Minahasans have strategized themselves in a competing arena of citizenship discourse in post Reformasi Indonesia.

This article attempts to analyze the dynamics of Minahasan collective actions in early 2000 in responding to the sectarian debates throughout the Indonesian archipelago where the issues of religion and ethnicity are flourishing. I draw on case studies from Kongres Minahasa Raya (the Great Congress of Minahasan) as entry point to explore the ways Minahasans have been peacefully demanding serious attention to and clarification on constitutionally-based provisions of citizenship in Indonesia. I explore how such "collective strategies" are created and maintained as an example of how citizens' arenas and rights are contested in contemporary Indonesia

\section{Minahasa: socio-historical setting}

Historically, Minahasa's connection to the outside world is attributed mainly to economic enterprises and is not a new experience since it first occurred during the colonial period. In Minahasa, the connection with "others" initially was set in motion by the Dutch in the eighteenth century. Prior to that and being tribal communities in their own right at that time, Minahasa as a collective identity did not appear as such. However, it can be argued that the conceptions of community, identity or territoriality began to take shape and meaning soon after its interaction with Western civilization, in the form of the Dutch.

As noted by Lundström-Burghoorn (1981), Schefold (1995), Henley (1996), and Schouten (1998) and Kipp (2004), Minahasa produces and exports significant amounts of clove, coffee, and copra to the China and Western countries on a sustainable basis. An important fact about Minahasan collective interests in economic development is that Minahasans have used economic reasons and political recognition in articulating their own collective imagining project.

Christianity has successfully brought Minahasan society and its life practices and imagination to the outside world. Minaha- sans have projected themselves as representatives of the modern ethnic community because of their exposure to European culture since the eighteenth century. Because of this long-standing exposure there is very little culture shock and other social repercussions felt by Minahasans. They come face to face with globalization with confidence and preparedness (Thufail 2012).

Christianity was one of the foremost foreign values that Minahasans received through globalization in the eighteenth century. By globalization in the context of the eighteenth century I mean a one-way flow of human interaction and exchange through a colonial system where one nation imposed its way of life on another. In this regard, knowledge, economic interests and foreign religions were the catalysts of a oneway change imposed on the Minahasans by the Dutch. Minahasans were merely the receivers of Dutch values and way of life with the latter being the transformers.

The life of Minahasans in the twentieth century is merely the legacy of this transformation but with a dynamic dimension. Not only did the colonial period caused a one-way transformation, it also indirectly raised an awareness for internal power struggle. Local culture and the need to express its manifestations became articulated and dynamic. This involved searching from within the society and reacting to any kind of knowledge and external influences. Minahasan literature and intellectuals have arrived at a historical epoch where active participation and agency and autonomy of Minahasa in terms of its collectivity have been more powerful in responding to the new form of globalization (Jacobsen 2002).

When I asked my sources to express their experiences and opinion about globalization, the majority gave self-confident answers. One respondent said:

"As a Minahasan we are not so shocked with globalization. Globalization is natural. We can see many foreigners here because Minahasa or North Sulawesi is a peaceful region and we have wonderful places for tourism. We welcome everyo- 
ne. We are an open society. Although foreigners have different habits and life style we can understand diversity. But they still need to respect our culture here... which is not as free and open as Western culture." (Interview with NG, General Secretary of GMIM)

Today, evangelism has become phenomenal in Minahasa in particular and North Sulawesi in general. Minahasans have been urged to convert and bring the gospel to non-Christians. They are said to be under a pressure of "global denomination" in Christianity. According to the former secretary of Minahasan Evangelical Churches (GMIM), there are around 8o Christian denominations in North Sulawesi, including Minahasa.

According to the former secretary of Minahasan Evangelical Churches of GMIM, the majority of the protestant denominations came from the United States of America. In fact, the US is largely responsible for exporting new kinds of Christian Protestantism. According to one of my informants, "Minahasa is a small America". It is due to this trend that we can see here a religious phenomenon like in America, where various theological perspectives flourish such as "Success Theology", "Welfare theology, etc".

To some extent Christianity in contemporary Minahasa is a mixture of influences first from Europe, as a result of the Dutch missionaries of the eighteenth century, and now from the American Protestant expansion. It will be seen that Christianity has gone on to provide the foundation for the creation of Minahasan identity. The findings pointed out above imply that globalization is a process whereby networking and connections are created and expanded either materially or spiritually and over time.

Because Minahasan society is an open society, this makes it easier for Minahasans to adopt any kind of changes in ideas and life practices, including forms of spirituality and deity. It is accepted that Minahasa is a Christian region. But to support a thesis about globalization being facilitated by Christianity, we must provide illustrations.
Attention is thus drawn to the significant rise of the Seventh Day Adventist communities and Pentecostals in Minahasa. During my field trip I found that many public religious gatherings and festivals were enthusiastically organized by both Adventists and Pentecostal communities, including one that was organized before the election of the governor in North Sulawesi.

Borkenhagen (2003, p.76) reported that Seventh Day Adventist communities have a strong connection with their US counterparts. Minahasans living in the United States facilitate, directly or indirectly, church facilities of Minahasa Adventists. Minahasa has a significant number of migrants living along the East coast of the U.S mainland. Borkenhagen's study has mentioned one place in Minahasa which had a special connection to the US where Minahasans live. This place is one of the Minahasan sub districts, called Langoan. When I was in Langoan, I saw many good houses and when I asked how they could build such good houses, they answered: "it is because of dollars..."

\section{Outside World and Church Organiza- tion}

Although this study is not about religion, it is relevant to discuss religious factors, particularly Christianity in the hope of understanding the development and dynamics of Minahasan identity via the process of globalization. Christian Minahasans have substantially involved and participated in globalization. Minahasan churches and their leaders have contributed significantly toward strengthening their respective denominations worldwide. Here I tried to list some global links of Christian Minahasans. When I asked about Christianity, one of my Minahasan respondents replied:

Basically Christianity is a foreign religion for us. Before the Dutch and Germany missionaries came in Minahasa we had natural religions. Our belief system is more in natural ways in approaching the sacred. We learn and interact within nature. We have rituals, symbols and lea- 
ders to help us understand the supernatural. So, Christianity is a product of our interaction with the West, particularly the Dutch. What we received from them is a new thinking in religious life. The only thing I know is that Christianity pushed us to be a modern society. We are not only following the Christian theology and its rituals but also practicing the Western style in daily life..." (Interview with RS, vice chairman of GMIM Church of Minahasa).

It is thus clear in Minasahan minds that Christianity was the force that transformed Minahasan life, cognitively and socially. Concepts of social life was seen differently and came with their own sets of values and rituals. Slowly but surely the life systems of Minahasans changed, although in the beginning there were significant resistance from the local spiritual leaders. As Schouten (1999) puts it, Christianity definitely contributed to a social differentiation among Minahasan people. Traditional forms of leadership and social relationships changed significantly as Christianity spread across Minahasan land. Christianity in Minahasa, Richard Siwu argued:

On the one hand, transformed the traditional "symbolic universe" from Opo, an ancient local name of God, to Christ; on the other hand, it transformed the society or social system from the old pattern to the new one...Unlike the old religion which focused on "totalistic-naturalistic" relationships, Christianity is rather a "personalistic" religion. As a result there is segregation between the sacred world and the profane world. Christianity has also adopted and accommodated elements of traditional culture. Put differently, while carrying out its "historical elements", Christianity also underwent "indigenization" or "inculturation". These changes can be seen in ceremonies and celebrations in contemporary Minahasan society. The transformation of Christianity appears as a "public religion" or a "new culture" to the Minahasan people." (Siwu 2002, p.85-87, 100).

Siwu $(1985,2000)$ has written a nice description on how Christianity and modernization influenced Minahasan life. Siwu's central claim is that Christianity adopted aspects of modernization and then spread its influences to other non-western countries. According to Siwu, there are three major catalysts of modernization in Minahasa: technology, bureaucracy and pluralism.

Taulu has noted that: "In Minahasa, the most effective institutions by which modernization is diffused are modern mass communication, school (education) and hospitalization. Christianity since the early time of its arrival in Minahasa has pioneered in operating these institution..."(Taulu 1952 in Siwu 2000, p.101-102). This process of modernization was greatly assisted by the processes of rationalization and secularization via churches.

Nowadays, Minahasa is facing challenges in these modern structures where relations between rationalization and secularization seem to compete to some extent. Minahasan need to preserve their homeland image as a Christian land and at the same time need to make a claim as a modern land. It is sometimes said that Minahasa is the "land of peace and a thousand Churches".

The former secretary of Minahasan Evangelical Church had participated as a member of the program committee of the Christian Conference of Asia (CCA) between 1995-2000. In 2000, the CCA held an assembly meeting in Tomohon City, Minahasa. This event was held at a time when many countries issued travel warnings to their citizens wanting to visit Indonesia. According to one respondent, "through this (assembly meeting) we have shown that Minahasa has a power to present different but positive images of Indonesia. We have peace, and we stand for peace and humanity..." (Interview with HW, Church leader, Manado, 10/20/05). Since 2000, Minahasan Christian leaders have hosted many international gatherings in North Sulawesi, such as Consultative Meeting of Youth Commission of the World Council of Churches, Executive Meeting of World Alliance of Reformed Churches (WARC). The latest was the Pre-Assembly of World Council of Churches for the Asia- 


\section{Pacific Region.}

The former secretary of Minahasa Evangelical Churches, has pointed out that Minahasan churches have contributed in church networking in Switzerland, Africa, Asia and Latin America. He further stated that:

"Since 2000, I was the president of Asia Fellowship of Mission 21 Partners which is based in Switzerland. Through this fellowship churches in Switzerland and Asia (India, Japan, Korea, Taiwan, Hong Kong, Malaysia and Indonesia) have been involved in building partnership to solve common problems and issues. One of the important programs in this partnership is interfaith dialogue. We already realized this program in Java with a joint program with Youth Ansor Organization, a prominent Muslim organization and the Pasundan Church in West Java region. And since 2004 I was elected as a vice president of the Synod's 21 Mission. This is a legislative institution of the international fellowship..." (Interview with NG, General Secretary of GMIM, Minahasa)

The former secretary also mentioned that Minahasa hosted the Assembly of Asia Fellowship in April 2006. He was twice elected as a representative of Asia in consultative policy sessions on the issues of economic justice and environment. In 2004 he participated in two international meetings, the first was in a South-South consultative meeting in Buenos-Aries, and the second in North-South consultative meeting in London.

When I asked one of the leaders of the GMIM about the motivation to be a host of international meetings in Minahasa, he stated that:

“...it is to show our Minahasaness in our Churches. What we found is that all participants felt that our churches are the "people churches". It is very popular and rooted in people's experiences. When we host an international meeting, all participants stay in Minahasan houses, not in hotels or elite buildings o everybody can taste Minahasan food, culture, and tradi- tions." (Interview with NG, General Secretary of GMIM, Minahasa)

Generally all the Minahasan respondents explained that information technology is a main driver of globalization. It is very positive because we can learn from others and we can add our knowledge every time. Many respondents claimed that Minahasa has embraced the latest in information technology particularly the internet and its easy and reliable access global interaction and exchange.

What has been presented above is an attempt to argue that the Minahasan identity is a social construct created out of three interrelated forces in history: globalization, nationalism and regionalism (ethnicity), and evangelicalism and ecumenism.

\section{Identity Articulations: Ethnic-based organization}

\section{Kerukunan Keluarga Kawanua (KKK)}

This part will look at some of the ways in which Minahasans have preserved their collective identity through the utilization of community-based organizations and their networks. The Kerukunan Keluarga Kawanua, KKK ("the Concord of Minahasan Families") is one of the popular ethnic-based organizations of Minahasans based in Jakarta. Until recently, this organization has been active involved in representing and organizing Minahasan collective activities and programs in Jakarta, particularly for social events.

Discussion in this session is based on an intensive survey of the KKK's website and field interviews with several leaders and advisors of the KKK. The KKK was established in the 1970s by several Minahasan elites in Jakarta. Some of the founders of the KKK were former politicians, businessmen, teachers, and some generals from the Indonesian army. Others were social activists from all walks of life based in Jakarta. At that time in the 1970s it seemed that that Minahasans in Jakarta were not as conscious of their collective identity as they are today. This was because the name of the organization rep- 
resenting their collective interests did not reflect that particular purpose.

In 1973, after a series of meetings in Jakarta the organization's name was changed to "Kawanua" (a Minahasan word for brotherhood). The name change was inspirited by the Minahasan cultural foundation. Back then, the idea to celebrate Minahasan ancestral ceremonies had arisen and thus symbolized the establishment of a Minahasan community-based organization. Being the nation's capital Jakarta provided the opportunities for Minahasans to celebrate their traditional cultures and heritage during national cultural occasions. In the 1980s, the leadership of the KKK changed hands. Ventje Sumual, a former leader of the Permesta Rebellion in 1957, was elected to lead and under his leadership KKK managed to expand its membership to include people from homeland Minahasa and outside of Indonesia.

The expansion of the KKK network at the international level was beneficial to the local cause. By the mid-1980s it had branches in California and New York and under Sumual's leadership economic activities and education of the Minahasans became priorities. One of my respondents mentioned that the KKK did provide scholarships for Minahasan to achieve high levels of education and that in the 1980s many Minahasas attained their PhDs in Java (Matindas and Supit 1998).

On the economic front, Sumual established many companies to support Minahasan enterprises. He went on to successfully initiating the establishment of credit banks in Minahasa region. These banks assisted Minahasan farmers by providing capital, human resource development support, financial management advice, and helped to market their products. These opportunities helped to exploit Minahasa's agricultural products and cash crops. Thus Sumual's contribution to the Minahasan economy and social progress is remarkable.

Until today, KKK is still plays an active role in integrating Minahasan people in Jakarta and has spread its activities to almost all the major cities in Indonesia and other countries in Asia, Europe, and the U.S. The KKK is also active in stimulating cultural activities and performances as well as cultural programs in Jakarta. In a way KKK represents a typical common social location for an ethnic group to foster its common identity regardless of national boundaries, time and distance.

This is consistent with popular observations which suggest that ethnicity is a powerful variable when it comes to unifying and to mobilizing individuals' collective action and activities outside of their places of origin. Self- identification, cultural understanding, and social boundaries are maintained by the ethnic community itself. This tendency is enhanced by the dynamics of contemporary social life where circumstances and social structures play important roles in compelling individuals to develop the desire to belong to a certain group on the basis of some common or prior understanding. The social environment thus compels individuals in society to choose certain identities on many occasions in their respective lives.

According to most of my respondents, more Minahasans are believed to be living outside the Minahasan homeland. Despite this trend, Minahasans living outside the homeland are culturally connected to the homeland by way of feelings about their origin, ancestral lineage, land/region, and religion (Christianity). For this reasons, family ties and ethnic organizations are central functions of Minahasan society. According to the one of the KKK leaders in Jakarta, it is very easy to organize Minahasans to participate in Minahasan collective events because they are strongly connected in a common religion (Christianity) and a deep sense of place and family. According to the KKK website there are at least 185 family groups, subethnic associations and social organizations all affiliated to the KKK.

The KKK's website statistics showing the number of visitors, for example between January and March 2006, present some interesting data. Visitor/viewer number and location are as follows: the U.S (6617, 44.4\%), Indonesia $(4052,27.2 \%)$, the Netherlands 
(1397, 9.4\%), Australia (435, 2.9\%), Japan (267, 1.8\%), Hong Kong (267, 1.8\%), Germany $(163,1.1 \%)$, Canada $(156,1.0 \%)$, UK (144, $1.0 \%)$ and Singapore (120, $0.8 \%)$. The webmaster stated about 40 people visit the website everyday. We cannot, however, be sure whether or not these visits are from bona fide Minahasans or other internet surfers stumbling upon the site by accident or curiosity.

On the other hand, though, such ethnic-based websites are becoming more useful and powerful forms of media that are cheap, fast and effective. The KKK website tends to present routine news in a more dynamic, animating manner. The website also runs interactive communication for visitors and Minahasans alike wherever they may be.

\section{Identity-based collective action}

This section describes the Great Minahasan Congress (Kongres Minahasa Raya) of 2000 and 2001. These moments form an integral component of Minahasan collective identity and action in contemporary Indonesia politics. Before I proceed to explain those moments in detail I will, firstly, present several political contexts within which the significance of the Great Minahasan Congress is to be understood.

\section{National Circumstances}

It should be noted that for about 40 years, Minahasan politics remained stagnant. This is attributed to the crushing of the Permes$t a$ rebellion of the early 1960 s by the central government and its military (Harvey 1977; Leirissa 1997). This official action caused the Minahasa people to become powerless and also discouraged them from embarking on projects of collective action and identity. With the demise of the Permesta, Minahasans lost their political clout and leverage which used to be the tools used to negotiate and bargain with the central government for political recognition and economic development. In the aftermath of the Permesta crushing, Minahasans experienced a state of political pessimism because all the Permes$t a$ leaders had been arrested and at the same time Minahasan economy did not look pro- mising. Hence Minahasans had to confront and deal with two serious crises: loss of political power and economic independence. It was at that time too that the prices of agricultural products decreased due to the monopolization and distribution of the market forces by central government corporatists.

During the New Order of Soeharto (1966-1998), Indonesian politics was described by political scholars as the politics of the "floating mass". This was an era of diminishing political and democratic participation. The state exerted a tremendous amount of official hegemony on the entire political life of the people and adopted a cultural discourse prescribed by the state machinery. In other words, the authoritative nature of Indonesian politics provided a system where the military institution, commercial corporations, and political parties were brought under the control of President Soeharto's power. However, all this changed in 1998 soon after the Asian economic crisis in 1997. The change gained momentum when students, NGOs, political activists, and the mass media joined forces to bring down the authoritative regime and thus usher in a new political landscape for Indonesia.

I argue that politics of identity is bounded up with the prevailing political circumstances. Whether Indonesian politics has significantly changed since 1998 remained to be seen. In terms of state formation and elite composition the indication is that the "Reformasi" was adopted to appease the anger and frustration of the civilian population that included students, political activists, and other interest groups. The most effective groups that were applying a tremendous political pressure on the government of the day were the university student groups. They were able to create among themselves a sense of common solidarity and purpose and being able to consolidate their political agendas and ideals of good governance.

From 1998-200o, Indonesian politics was in an uncertain stage and faced by looming crises from all sectors of society. In the political arena, free and fair elections were needed in order to install a democratic government and its administration. To achieve 
that, one had to take into account the fact that there were forty five political parties and strike a balance between their political agendas and the overall national priority. In the economic arena relief programs were needed to tackle poverty and meet the basic needs of the people in the aftermath of the Asian financial crisis. In the cultural and ethnic domain, Indonesia was facing problems of self-autonomy and self-government from the various ethnic groups within the country. Ethnicity and religion became crucial players in the multi-cultural society in that people had to wake up to the reality of the new political atmosphere.

There is one other thing that is worth mentioning concerning the political contexts of identity construction: Since 1999 communal ethnic conflicts have emerged significantly in certain areas of Indonesia, namely the Moluccas region, Central Sulawesi, West Kalimantan and Nusa Tenggara. These areas are known for their multi-ethnic and multi-religious groups. The situation becomes "crucial and sensitive" when religious questions and issues are taken into account especially between Muslims and Christians and the indigenous population. By crucial and sensitive I mean how each ethnic and religious group perceive its right to be recognized and subsequently compete to acquire economic and political resources and recognition.

A diversity of political discourses may emerge and some of them may be able to provide solutions if not address the diversity of Indonesian society. For example political consensus is a favorable means of achieving harmony in certain regions. In North Sulawesi the division and distribution of political positions in the legislative and executive arms of government are done through "consensus" among the ethnic and religious groups. Some areas have successfully used their historical capital as necessary tools to initiate conflict resolution programs at the local and regional levels.

After the reformation era (since 1999), questions about multiculturalism began to emerge. People began to ask themselves why communal conflicts still persist. Why is their historical tradition of consensus and other cultural values not providing any meaning nor helpful anymore? Who are the main actors in conflicts and how do we identify them? Who has gained from such conflicts? As a former freelance journalist and activist, I was working intensively in creating conflict prevention programs in my region, North Sulawesi. What I found was that different interest groups and stakeholders were employing "conspiracy theories" of political manipulation and maneuvering when things did not go in their favor. Although the idea of conspiracy theories is not directly related to this article, it seeks to contextualize identity construction and communal conflicts: That Minahasa is one of the hot spots of Indonesian politics and that one must look for ways and means to reduce communal conflicts based on ethnic and/or religious grounds.

For Minahasans, the specter of sectarian conflict is ever present and somewhat sensitive. Thus any politically-related issue or collective protests, petitions and action must be collectively initiated. This study has noted the case of the KMR in 2000 and 2001, where collective action was based on a combination of ethnicity and Christianity.

One of my sources in Jakarta explained that the phenomenon of KMR is a reflection of "minority syndrome". He argues:

\footnotetext{
"Minahasans understand that it will be impossible for Indonesia to become an Islamic state. Radical groups must be suppressed by the state laws and the constitution. Of course, the government's various discourses always confuse our minds. We will continue to oppose sectarian interests that are promoted by particular individuals and their groups. This is to prevent the government from catering to the interests of just one group (Interview with MW, a leader of Minahasan ethnic organization, Jakarta).
}

Political action and/or movement such the KMR was an excellent example of identity articulation and local interpretation of significant moments and leadership responding to external and structural cir- 
cumstances.

\section{Minahasans in Indonesian Political Transition \\ Questions on Identity through political memo- ry and political imagination}

The Great Congress of Minahasan or Kongres Minahasa Raya (KMR) was held on August $5^{\text {th }}, 2000$ and July $17^{\text {th }}, 2001$ in Bukit Inspirasi Tomohon (the Tomohon Inspiration Hill). The congress was deemed successful by both the locals and those from the other parts of the country; about 2000 people attended both meetings and actively participated. The participants came from different backgrounds such as religious leaders, ethnic leaders, youth organizations, professionals and politicians. Groups from the US, Europe, and Australia, etc. sent in their representatives.

The congress was covered extensively by the news media. In determining news framing and stressing, different styles were used by the local and national media. For example the Manado Post $4^{\text {th }}$ August 2000 ran the provocative headline: "The Minahasan Congress is to Save Indonesia" (Kongres Minahasa Selamatkan Indonesia).

During the conference, patriotic speeches were uttered and subsequently recorded, like this one:

Now is the time for all Minahasans and their descendents living in Minahasan homeland and outside of the homeland, to be committed to the Minahasan culture while loyal to the Indonesian nationstate...

And this:

The people of Minahasa are committed to strengthening Minahasaness, and also committed toward Indonesia. They will strive to identify the best alternatives for Indonesian national development and think up new directions for the future.

I perceive these remarks to be positive and clear. Through these kinds of utterances we can come to understand the basic reasons of the KMR from the outset. The two congresses are indications of a consolidation of a common Minahasan identity. In fact, the result of the congresses was a political petition to the Indonesian government for political recognition and participation at the national level. The KMR is not an ethnic congress but a collective social movement. This became obvious that soon after the congresses, KMR leaders resolved to petition the central government for their voice to be heard and represented in government.

\section{The Great Minahasans Congress}

\section{Elite and public perspective}

In his biography, Marhanny V.P. Pua, a Chairman of the Great Minahasan Congress stated:

This congress is open to the public. It is not an exclusive congress just for Minahasans. It is for all North Sulawesi people and for those who want to participate in delivering ideas and concerns toward the destiny and the future of this nation" (Isnaeni 2004, p. 71).

In the front of the news media, Hanny Pua made a strong assertion that:

This congress is a protest movement or a political interruption as our response to political disorder where sectarian politics has arisen to give an impression that Indonesia is owned by certain groups of people. We criticize this condition. This congress intends to remind the Indonesian people to be consistent in preserving our national commitment founded in the 1945 constitution. The constitution is the result of wise and collective decision by our founding fathers. We have seen that a certain group in this nation has made a political agenda to reintroduce Piagam Jakarta, which is a special status for Muslims in the constitution" (Isnaeni, 2004: 72).

It was clear then, that the Minahasan congress was more than a reactive means to protest national trends that are detrimental to the whole nation. Sectarian politics was the main issue taken up by the Minahasa congresses to oppose radical Muslims who 
tried to provoke and undermine the political institutions in order to legitimize an exclusive position and rights for Muslims. The leader of the KMR asserted that:

This congress shows our commitment as Minahasans to Indonesia. We stand committed to the integrity of Indonesia as our country and we are fully involved to ensure that all national affairs are on the right track. We strongly reject any effort to change Indonesia into a country based on Islamic laws. There are already signs warning us about this problem. Our concern should be directed at addressing sectarian violence in Maluku, Poso and other places (Interview with HP, leader of the KMR, 12/17/05).

The other purpose of the Great Minahasan Congress was to reinforce a sense of Minahasan values amid the multicultural society of today's Indonesia. Hanny Pua stated that Minahasans have a special status because of their unique culture and historical emergence and therefore they needed to be respected and treated equally like other ethnic groups in Indonesia.

The Minahasan congresses reflected a new way of using collective action based on ethnicity to criticize political tendencies in contemporary Indonesia. What the Minahasans called for was political recognition for all ethnic and religious groups that would guarantee them equal rights and respect before the constitution.

Many Minahasans living outside of the homeland have different points of view about how Minahasans should respond to discourses in the politics of identity, particularly those radical groups who are pushing for an Islamic state. As explained by one of my respondents:

Minahasans should not be worried about this issue (Islamic state). The majority of Indonesian Muslims do not support or condone sectarian group agendas. We have heard and seen how some Muslim leaders reject this matter. However, we should understand that in a democratic society we do not have the right to stop differences in political directions and ide- ology. Everybody can express their political opinion. The only thing we are totally against is violence and political egoism. As a Minahasan, of course, I really understand that we should struggle to protect our country from becoming a theocratic country, where religion and cultural identities become homogenized..." (Interview with RM, Minahasan activist, Manado, 9/5/05)

The KMR in a way reinforces Minahasan collectivity in a sustainable manner and shows, and at the same time, the challenges and threats of its existence politically or culturally. As shown by the many texts found in speeches, proceedings and media coverage, the KMR is significantly reinforcing cultural narratives and ideals of how to be a Minahasan. Ultimately the KMR is representing the ideals of Minahasa as an exceptional entity with egalitarian and democratic values embedded in its common consciousness. When Minahasan elites speak about Minahasan nationalism they always refer to all the great Minahasan heroes some of whom are intellectuals, military leaders and politicians.

In his testimony on the role of the KMR, Hanny Pua reminded the public that Minahasan values include a deep love of peace, dialogue and egalitarianism as means to achieve harmony, prosperity and progressive knowledge. It would be seen that these ideals are absolutely relevant at this moment of Indonesian unity. Hanny's concern was that the KMR should be seen as a moral beacon to keep Indonesia on the right track by safeguarding the diversity of the people.

Thus Minahasans are relatively openminded and embrace opportunities as they come at both the national and international levels. Minahasans are also sensitive to government policy in giving recognition to local aspirations. This has resulted, since 1999, in the shift in central government attention to issues of autonomy and decentralization to suit local needs and circumstances. Although the KMR's guiding principle is concerned with the politics of identity, it still encourages Minahasans to find strategies on how integrate local unity with national uni- 
ty. The guiding principle also reminds Minahasans of the need for political convergence and accommodation of competing interests as a means to promote harmony and unity. When responding to such matters, one respondent who was the former secretary of the GMIM (the Evangelical Christian Church of Minahasa) stated:

\begin{abstract}
"The KMR is simply voicing Minahasan political protest. I like it that way. No violence. But I really understand that in Minahasan homeland we have different points of view on this issue. Some of us want to be an "independent state", but the majority of Minahasans is highly committed to being a part of the Indonesian nations-state. Our ancestors were also the founders of this country. But one thing should be clear: Indonesia is not as a state based on any particular religion. If the majority of the groups change their commitment to the national union and embark on a state based on a particular religion, it means that this country has practically thrown out Minahasa and the minority groups of Indonesia ..." (Interview with NG, Minahasan leader, Manado, 9/5/05)
\end{abstract}

This statement clearly indicates the dynamics of identity politics in Indonesia since the downfall of the Soeharto regime in 1998. The post-Soeharto era saw a proliferation of cultural identity projects undertaken by various interest groups to address their respective regional and local issues. Thus democratic conversations and dialogue began to emerge to embrace political, economic, and cultural concerns of the interest groups. When the autonomy bill was passed in 1999 provinces and districts began to manage their own development programs and leadership mechanisms based on their own resources and identity. Since then discourses on provincialism and secessionism began to assume peripheral status. With this new political outlook new political vocabularies began to come into usage. In Minahasa for example, local language and names replaced the popular names and titles of the Soeharto era.

In this section, I attempted to focus on the views of leading actors of the KMR as a means to understand the common narratives that were employed to mobilize collective action and identity.

As a Christian community, HP, for example, states that:

God is present in Minahasan land. He helps us to work together to build our nation and respect each other. We follow what God says and believe that faith without action is dead (Interview with HP, Minahasan youth Christian leader, Manado, 12/17/05)

One of my sources who attended the two congresses KMR I and II argued that:

"The Great Congress of Minahasa was not entirely a Minahasan aspiration. We know that we all share similar ideas and sentiments but the KMR was clearly created by a particular interest group of Minahasan. I felt that there might be a group of Minahasan elite in Jakarta who orchestrated this event. And I believe these events were connected with their interests particularly in order to show the Jakarta government and bureaucrats that Minahasan leaders should be accommodated in the national government administration. For a long time Minahasans have been given token gestures of recognition and inclusion. We will be happy to see one or two Minahasan ministers or whatever position that is available. Those Minahasan elites in Jakarta who are interested in those government positions will support what the KMR is doing because they stand to gain from the proceedings (Interview with AS Minahasan activist, Minahasa, 11/3/05).

Although the KMR of 2000 and 2001 represent a significant form of Minahasan collective action, it does not mean that these events provide the total unifying force for Minahasan social and political aspirations. Minahasa like other societies may never achieve a single voice in political affairs. Each faction and individual within the larger Minahasan establishment may have different opinions and approaches to issues and problems.

Despite this hurdle, it is obvious that 
Christian activists and their functionaries seem to have a single voice and that is the commitment to be an integral part of the Indonesian nation state. This faction utilizes group memories and common histories of Indonesia as a whole and Minahasa in particular for the greater purpose of preserving national unity. Of course there are some professional individuals who tend to assume bystander status and do not participate actively in communal activities. Most of them are businessmen and bureaucrats who work in government administration. In contrast, there are groups and individuals who tend to be more heroic and emotional in their aspirations, particularly to endorse Minahasan as an independent state.

In short I argued that the KMR of 2000 has presented a two-sided meaning to ethnic-based collective action: firstly, demanding political recognition and calling for equal rights for all citizens, and secondly, providing a public forum for collective discourse and debates in promoting democratic principles and national unity in the long run.

\section{The KMR: Impacts and Meanings}

A couple of days after the first KMR ended, a delegation was sent to Jakarta to make representations at the national parliament. The purpose of the delegation was to ensure that any amendment to the constitution must recognize multiculturalism and religious freedom. The amendment concerned the preamble of the constitution that contained the basic principle of the state ideology.

The KMR delegation was reported to be well-prepared in their agendas to deal with the constitutional amendment that was related to sectarian politics. There were other lobbyists and pressure groups including political parties and religious interest groups. The KMR delegation successfully met and held discussions with the Chairman of People's Consultative Assembly who was to chair the constitutional meeting. $\mathrm{He}$ is Mr. Amin Rais, a chairman of the National Mandat Party. Mr. Amin has a Ph.D from Chicago University in political science, and was a former chairman of the second biggest
Muslim organization, Muhammadiyah. He is well known as an intellectual and university professor.

Mr. Amin listened carefully and respected the Minahasans' misgivings about the idea of an Islamic state. He then gave the guarantee to all Minahasans and the Indonesian people that he would fight hard to preserve democracy and the inclusive system of Indonesian politics while keeping in mind the constitution as the overall guiding principle. To consolidate Mr. Amin's commitment, the leader of the KMR delegation, Hanny Pua, exhorted him to take a serious role to block any sectarian demand from radical groups who intended to change Indonesian state ideology.

Perhaps it is appropriate to use part of the reported conversation between the two men. Mr. Pua said the following to Mr. Amin:

\footnotetext{
"Mr. Amin, lying in your hand now is the future of this nation. Do not let sectarian demands and egoistic minds use religion as the basis of politics to divide the people. Do not ignore our history. If the constitution is amended to make this country an Islamic state, it will also be our right to decide our own future as an independent state" (Isnaeni, 2004: 83)
}

Hanny made a similar speech in the presence of President Abdurrahman Wahid during the second KMR in 2001. He stated: "We are not second-class citizens in this country. Our ancestors were also the founders of this country. Our status in this country is not like renters. We are the owners, too..." (Interview with HP, leader of the KMR, Manado).

In some way the contexts and ideas of the KMR delegation in lobbying and demonstrating Minahasan aspiration in Jakarta was impressive and provocative at the same time. There was also passion in what they did in Jakarta mostly as a serious reaction to reject the inclusion of Islamic laws (deemed to be exclusive in nature) in the constitution.

The annual meeting of People's Consultative Assembly is a special moment in 
Indonesian politics because of its authority in making political decisions of the highest order. It is constitutionally authorized, for example, to impeach a president or to amend the constitution on the basis of popular consent. During the Soeharto regime the Assembly applied a consensus system in its decision-making processes, particularly because the Assembly was authorized to elect the president. This all changed in 2004 when Indonesia adopted the system of free presidential election. Before 1999, however, radical groups, exploited this provision to push their own agendas particularly in integrating Islamic principles/laws into the constitution.

It is reasonable that a democratic system allows people to present different point of views and interests. But, on a philosophical level, especially regarding the state and nation, people need to understand more deeply the historical background as well as the social and cultural facts that inform a system of government. In fact, since its inception as a nation, Indonesia implicitly declared its philosophy of "Unity in Diversity" and went on proclaim as a democratic country that is based on the laws and principles of republicanism.

\section{CONCLUSION}

This article shows that nationalism, regionalism and globalization can be very productive in a democratic society. It is productive in the sense that the regional aspect is naturally objective for Indonesia in the context of an "Islandic nation". The flip side of this is that citizenship can become problematic where the process of globalization and national aspiration is likely to shift political landscape of local interest groups and reorient their desire to be self-governed. National politics may also have the tendency to weaken the legitimacy of the state causing it to become less autonomous and powerless in serving its citizens effectively. This observation may be speculative but it is relevant in the context of contemporary citizenship politics.

The Minahasan identity is emerging in an environment of socio-cultural transformation in the wake of globalization and national politics where social interactions and ethnic networks flow at different levels. Globalization has influenced Minahasan life through several forms. Firstly, by adopting and adjusting the ideas of democracy, civility, cosmopolitanism and inclusivism. Secondly, Minahasa's local institutions are connected to international activities, like the "Church connections", education and trade. In the past years, local Minahasan organizations have hosted many international and regional gatherings in Minahasa. Thirdly, Minahasans have extensively employed the media, including the new media (Internet) to connect local Minahasans and their compatriots living abroad. Moreover, the Minahasan media are dominated by Minahasan diaspora creators and these efforts are support by Minahasan elites. The Minahasan diaspora has been active in maintaining Minahasan images and ideals through the media and ethnic-based organizations.

\section{REFERENCES}

Bertrand, J., 2004. Nationalism and Ethnic Conflict in Indonesia. Cambridge University Press, New York.

Borkenhagen, L.M., 2003. Minahasa's Clove Agriculture: The Church and the Production of Power Though the Indonesian State. PhD Dissertation of Environmental Science, Policy and Management. University of California Berkeley, Berkeley.

Brickell, T., 2013. Three trips to Minahasa. RIMA: Review of Indonesian and Malaysian $A f$ fairs, $47(2)$, p.117.

Castells, M., 1997a. The Information Age: Economy, Society and Culture. Volume II. The Power of Identity. Blackwell, USA.

El-Haj, T.R.A., 2009. Becoming citizens in an era of globalization and transnational migration: Reimagining citizenship as critical practice. Theory into Practice, 48(4), pp.274-282.

Haigh, M., 2008. Internationalisation, planetary citizenship and higher education inc. Compare, 38(4), pp.427-440.

Harvey, B.S., 1977. Permesta: Half a Rebellion (1977). Cornell University, Southeast Asia Program, Ithaca.

Henley, D.E.F., 1996. Nationalism and Regionalism in A Colonial Context: Minahasa in the Dutch East Indies. KITLV, Leiden.

Isnaeni, M., 2004. Marhany V.P. Pua: Kepribadian, 
Kepemimpinan dan Wawasan Masa Depan. Media Pustaka, Manado.

Jacobsen, M., 2002. On the Question of Contemporary Identity in Minahasa, North Sulawesi Province, Indonesia. Asian Anthropology, 1, pp.31-58.

Kipp, R. S., 2004. Two Views of the Minahasa; or, Whatever Happened to the Poor, Heathen Bushnatives? The Journal of Asian Studies, 63(3), pp. 597-624.

Leirissa, R.Z., 1997. PRRI - Permesta: Strategi Membangun Indonesia Tanpa Komunis. Grafiti Press, Jakarta.

Lundström-Burghoorn, W., 1981. Minahasa Civilization, a Tradition of Change. University of Gothenburg, Sweden.

Mannion, G., Biesta, G., Priestley, M., \& Ross, H., 2011. The global dimension in education and education for global citizenship: Genealogy and critique. Globalisation, Societies and Education, 9(3-4), pp.443-456.

Matindas, B., \& Supit, B., 1998. Ventje Sumual: Menatap Hanya Ke Depan. Biografi Seorang Patriot, Filsuf, Gembong Pemberontak. Bina Insani, Jakarta.

Schefold, R., 1995. Minahasa, Past and Present: Tradition and transition in an Outer Island Region of Indonesia. Research School CNWS, Netherlands.

Schouten, M.J.C., 1998. Leadership and Social Mobility in a Southeast Asian Society, Minahasa 16771983. Vrije Universiteit, Amsterdam.
Shultz, L., 2007. Educating for global citizenship: Conflicting agendas and understandings. Alberta Journal of Educational Research, 53(3), pp.248.

Siwu, R.A.D., 1985. Adat, Gospel, and Pancasila: A Study of the Minahasan Culture and Christianity Society. Thesis. Lexington, USA.

Staeheli, L.A., 2016. Globalization and the scales of citizenship. In Geography Research Forum, 19, pp.6o-77.

Thufail, F.I., 2012. When peace prevails on Kasih Hill: the Protestant church and the politics of adat in Minahasa. Asian Ethnicity, 13(4), pp.359-371.

Tiessen, R., 2011. Global subjects or objects of globalisation? The promotion of global citizenship in organisations offering sport for development and/or peace programmes. Third world quarterly, 32(3), pp.571-587.

Wawointana, T., Akib, H., Tahmir, S., \& Kerebungu, F., 2016. Role of Local Institutions "Mapalus" as a Basis of Public Service in the Field of Security and Public Order in Minahasa, Indonesia. The Social Sciences, 11(13), pp.3370-3374.

Wuisang, C., \& Jones, D., 2015, January. The value of ethnoecological knowledge of the Minahasans: repositioning traditional biocultural knowledge in Indonesian environmental planning. In ISDRS 2015: Vulnerability and Adaptive Capacity. Proceedings of 21st International Sustainable Development Research Society Conference (pp.1-11). International Sustainable Development Research Society. 